\title{
ヨーロッパに於ける俳句の受容
}

軌跡と展望

\author{
Willy. F. VANDE WALLE(ウィリー・F・ヴァンドゥワラ \\ Professor emeritus, Research Unit of Japanese Studies, Leuven University, Belgium) \\ 四willy.vandewalle@kuleuven.be \\ (ベルギールーヴァン大学文学部東洋学科名誉教授、日本学特任教授。日本文化史、日本 \\ 対外関係史、日本詩歌文学。主著に『俳諧から実験的現代詩まで』(オランダ:Amsterdam \\ University Press, 2003)、『Japan \& Belgium: Four Centuries of Exchange(日本・ベルギ——四世 \\ 紀に亘る交流)』(Brussels:Commissioners-General of the Belgian Govemment at the Universal \\ Exposition of Aichi 2005)、『日本通史』ベルギー：Acoo, 2014)、『日本とベルギ一一相互刺 \\ 激の道のり』(ベルギー： Lannoo, 2016) など。
}

\section{The Aoption and Adaptation of Haiku in Europe}

British scholars and several other Westerners who had mastered Japanese were the first to introduce the haiku to the West. In the early stages of its introduction, individual haiku were often compared to epigrams and maxims, and in translation they were even transformed into a rhyming format. However, from around the turn of the century the haiku was gradually recognized as a literary genre in its own right, and Paul-Louis Couchoud was one of the first to grasp its specific characteristics and qualities. After visiting Japan, he published a cycle of 72 "Hai Kai" about a boat trip on the river Seine in 1905. His sensitivity to the characteristics of the haiku was inherited by a new generation of French haiku poets, who adapted and transformed the form into a largely Westernized genre. The haiku even elicited interest among a number of leading European poets and novelists, who, while often adhering to European literary forms, experimented with the forms of sensitivity and perception they believed to be unique to the haiku.

After the Second World War, the publication between 1949 and 1952 by Reginald Horatio Blyth of several volumes of English translations of Japanese classical haiku, with commentaries, marked a watershed. These widely-read texts laid the foundation for the definitive popularization of the haiku genre in the West.

Keywords Haiku(俳句), Haikai(俳諧), Imagism(イマジズム), Paul-Louis Couchoud (ポール・ルイ・クシュー), Reginald Horatio Blyth(レジナルド・ホーラ ス・ブライス) 


\section{1 はじめに}

俳句がヨーロッパ文学への仲間入りを成し遂げるために、二つの条件が満たされな ければならなかった。日本の立場から見れば、まず徳川幕府政策の下で日本が閉じ込め られていた鎖国状態に、1854年に外国の圧力によって終止符が打たれたこと、そして西 洋との新たな接触が、正岡子規などをして、やがて民間の遊び道具に過ぎないものと退 化していた俳句を再定義させる機運が生じさせていったこと、この二つの条件である。

本稿のテーマは俳句であるが、以下に「俳句」という言葉を使う時は、日本語で書か れた俳句、日本語の原句が西洋各国語に翻訳されたもの、または俳句という抽象的な概 念を指す時、漢字の表記にする。西洋各国語で創作された原句は「八イク」か「ハイカイ」 として表記することにする。西洋では「ハイク」と「八イカイ」が混同して使用されてお り、統一していない。本稿でも、両方を適宜併用している。戦前は、特にフランスでは 「ハイカイ」の方が一般的に使われたが戦後になって段々「ハイク」の方が有力になり、今 や「ハイク」に統一していると言える。

\section{2 西洋への紹介}

西洋における俳句の最初の「紹介」は、日本語を習得した英国の学者やその他の西洋人 によって行われた。1877年、外交官且つ学者で、西洋における日本文学研究の先駆者と いうべきW・H・アストン(William George Aston:1841-1911)は、俳句の最初の英訳を世 に送った。『日本文語文法A Grammar of the Japanese Written Language』(1877)に収録 された3句の発句が、それである。それらの中の一句を引用しよう。

“Fuji concealed in a mist”という詞書きに続いて、“Into a sea of mist whither hath Mt. Fuji sunk?”という英訳を収録している。仮の和訳は、「霧に包まれた富士霧の海へは 富士は何処にか沈める」となるだろうか。

一方、東京在住の英国人教授バジル・ホール・チェンバレン (Basil Hall Chamberlain : 1850-1935)は、1880年に『The Classical Poetry of the Japanese(日本人の古典的詩歌)』 を、1888年には、更に一連の俳句の英訳も収録した『A Handbook of Colloquial Japanese(口語日本語の教科書)』を出版した。が、もっとも画期的なのは、世界中で広く 読まれるようになった、日本文学史を包括的に取り扱った、アストン氏の編集になる 『A History of Japanese Literature(日本文学史)』(1898)、および、チェンバレンが1902 年に出版した論文「Bashō and the Japanese Poetical Epigram(芭蕉と日本の詩的な警句)」 ${ }^{1}$ という2編であった。これらの2編は、日本語以外の言葉で俳句に関する評論を記載した

1 Chamberlain, "Bashō and the Japanese Poetical Epigram", Transactions of the Asiatic Society of Japan. Vol. 2, No 30, 1902. 
最初の論文と思われる ${ }^{2}$ 。後者の書名から判断できるように、西洋への紹介の初期段階 では、日本の俳句を西洋文学史に於ける既存の諸種ジャンルの中で一番類似的なものに 当て嵌めようとして、その理解に寄与しようとする努力が䙾える。その結果、俳句は本 来俳句の本質を心得ている筈のこれらの翻訳者自身によってさえ即座にエピグラムや格 言と関連付けられ、韻を踏んだ形式に翻訳されたり、また詞書きが追加されたりすると いう形で西洋に紹介されたのであった。しかし、韻を踏んだ形式に翻訳するのは咒長の 嫌いがあり、違和感を覚えさせる為か、韻律は早くも破棄されたようである。

『Glimpses of Unfamilar Japan（知られぬ日本の面影）』(1894)、『Kokoro：Hints and Echoes of Japanese Inner Life (ココロ：日本の心の生活のヒント)』(1896)、『Exotics and Retroperspectives(異国風物と回想)』(1898)、『JapaneseＬyrics(日本語の歌詞)』(190 0)、『Kottō：Being Japanese Curios, with Sundry Cobwebs（コットウ：様々なクモの巣 がついている日本の骨董品)』(1903)、『Japan：An attempt at interpretation（日本一一 の解明)』(1904)などの著作で知られている小泉八雲(Lafcadio Hearn：1850-1904)は、日 本伝統文化のある特定のイメージを西洋に紹介したが、俳句もその代表的なものの一つ として取り扱っている。『コットゥ(1903) の「Fireflies(ホタル)」という章では蛍のこ とを詠んだ一連の発句を掲載している。彼が採用したのは無韻の三行形式だが、17字の 音字は英語では困難だから、音節の数は不規則的である。いずれにしてもやがて三行形 式は、しかも5-7-5の音字で、英語以外の多くの言語でほぼ定着して、支配的になって いく。同書から原句のローマ字による音訳と英訳を数句引用しよう。

Mayoi-go no

Naku-naku tsukamu

Hotaru kana!

Ah! The lost child! Though crying and crying, still he catches fireflies!

Kuraki yori

Kuraki hito yobu :

Hotaru kana!

Out of the blackness black people call [to each other]: [they are hunting] fireflies!

Kusakari no

Sode yori idzuru,

Hotaru kana!

2 Trumbull, Charles. "One Hundred Bridges, One Hundred Traditions in Haiku - Part I", in Modern Haiku, An Independent Journal of Haiku and Haiku Studies, Volume 41.2, Santa Fe NM, Summer 2010, p.26. 
See! a firefly flies out of the sleeve of the grass-cutter!

Yo ga akete,

Mushi ni naritaru

Hotaru kana!

With the coming of the dawn they change into insects again, these fireflies!

Hotarubi ya!

Kusa ni osamaru

Yoakegata

Ah, these firefly-lights! As the darkness begins to break, they bury themselves in the grass $^{3}$

同時期にチェンバレンはその著作『Things Japanese(日本事物誌)』(1905)において俳句 を「ハイカイまたはホック、わずか17音節の最も短詩型（5，7，5）」と定義して2例の句を 挙げている。

\section{Rakkwa eda ni \\ Kaeru to mireba \\ Kochō kana!}

What I saw as a fallen blossom returning to

the branch, 1o!, it was a butterfly.

Yûdachi ya

Chie sama-zama no

Kaburi-mono

A shower, and head-gear variously

ingenious 4

一行に英訳しているハーンと違ってチェンバレンは、二行形式に翻訳している。

3 Hearn, Lafcadio. Kottō : Being Japanese Curios, with Sundry Cobwebs. New York: The Macmillan Company, 1903.

4 Chamberlain, Basil Hall. Things Japanese. London : John Murray, 1905, p.377. 


\section{3 翻訳の問題}

初期の翻訳は多くの難問を抱えていた。英語を初め西洋の各国言語と日本語との文法 構造が大きく異るのは固より、ヨーロッパの詩は韻を重視し、ヨーロッパの詩人が必ず しも簡潔さを好まないのに加えて、曖昧さは、空白ではなく、言葉によってこそ表現さ れるべきである等、詩歌論の基本的な概念も相容れないものがあった。その結果、一句 の翻訳でも多種多様である。それを具体的に示すのに、松尾芭蕉（1644-1694）による有 名な発句「夏草や兵どもが夢の跡」の幾つかの英訳をとりあげてみよう。

1)

Haply the summer grasses are

A relic of the warrior's dreams

(Basil Hall Chamberlain)

2)

Asleep within the grave

The soldiers dream, and overhead

The summer grasses wave

(William N. Porterウィリアム・N・ポーター, 1849-1929)

3)

Old battlefield, fresh with spring flowers again -

All that is left of the dream

Of twice ten thousand warriors slain

(Curtis Hidden Pageカーティス・ヒドン・ペイジ, 1870-1946)

4)

The summer grass!

' $T$ is all that's left

Of ancient warriors' dreams

(新渡戸稲造, 1862-1933)

5)

Summer grass

Where warriors dream.

(Kenneth Rexrothケネス・レクスロス, 1905-1982)

6)

Only summer grass grows

Where ancient warriors

Used to dream!

（Oseko Toshiharu尾迫利治, Basho’s Haiku『芭蕉の俳句』, 1990)

7)

summer grass :

all that remains 
of warrior's dreams

(David Landis Barnhill デビッド・ランディス・バーンヒル, Bashō’s Haiku

『芭蕉の俳句』，2004）

8)

summer grasses

where stalwart soldiers

once dreamed a dream

(Ueda Makoto上田真, Bashō and his Interpreters『芭蕉とその解釈者』, 1992)

それぞれの英訳を比較すると、二行形式を採用するチェンバレンとケネス・レクス ロス以外は、皆三行形式に徹している共通点が見受けられるものの、簡潔・圥長、書き 言葉・話し言葉などの相違点が多い。

さて、英語で最初の原作八イクは、誰の句作か？幾人かの候補者が挙げられる。そ の一人は日系アメリカン人の野口米次郎(Yone Noguchi：1875-1947)であった。その句 を引用しよう。

Tell me the street to Heaven

This? Or that? Oh, which?

What webs of streets!

(Through the Torii, 1914) ${ }^{5}$

天国への道を教えて

これ？またはそれ？ああ、どれ？

街の網状かな!

もう一人の候補者は有名な文学者エズラ・パウンド(Ezra Pound：1885-1972)であ る。その句は下記の通りである。

In a station of the metro

The apparition of these faces in the crowd:

Petals on a wet, black bough

(The Fortnightly Review $571^{6}$ 所収)

地下鉄の駅にて

群衆の中のこれらの顔の幻影 :

濡枕黒い枝の花びら

5 Yone Noguchi. Through the Torii. Boston: Four Seasons Company, 1914.

6 Ezra Pound, The Fortnightly Review 571, September 1, 1914, pp.465-467. 
またもう一人の候補者はサダキチ・ハートマン(Sadakichi Hartman：1867-1944)であ る。彼の句は下記の通りである。

White petals afloat

On a winding woodland stream -

What else is life's dream!

(Tanka and Haikai : Japanese Rhythms, 1916所収)

森の中の曲がりくねった小川に

浮かぶ白い花びら-

人生の夢

\section{4 フランスに於けるハイカイの導入}

さてフランスへ目を向けていきたいと思う。レオン・ドゥ・ロニー(Léon de Rosny (漢字名：羅尼）：1837-1914）は、フランスに於ける近代日本研究の創始者として知られ ている。同氏の編訳『Si-ka-zen-yō(詩歌撰葉)』の「Anthologie japonaise. Poésies anciennes et modernes des insulaires du Nippon（日本のアンソロジー、日本島民の古代と現代の 詩)」(1871) $)^{7}$ に短歌の最初のフランス語訳が収録されている。ロニーは日本文学、取り 分け詩歌に強い興味を持っていた。『万葉集』と『古事記』の一部を翻訳した外、彼の最も 広く読まれている編著が、『Si-ka-zen-yō』「Anthologie japonaise」であった。1871年に 出版されたこのアンソロジーは、ウィリアム・アストン(William George Aston : 18411911)から批判(1872年2月の『The Phoenix(フェニックス)』に掲載)を受けたが、スタニ スラス・ジュリアンといらフランスの有名な中国学者によって高く評価された8。オー ストリアのプフィッツマイアー(Pfizmaier)は既に1852年にドイツ語に『万葉集』の一部を 翻訳・発表していたが、『Si-ka-zen-yō』の「Anthologie japonaise」は相当の数の詩歌のフ ランス語への最初の翻訳解釈であった。ロニーは日本の詩歌の愛好家であり、日本語を 教える際『百人一首』などを教材に使っていた。ファーブルミュラー(Fabre-Muller)によ ると、『Si-ka-zen-yō』「Anthologie japonaise」は、全部で112首を収録しているが、7世 紀から16世紀にかけて詠まれたものがその大部分を占めているという。版によっては 計算が異なっているようであるが、中には、『万葉集』から 15 首、『百人一首』から50首以 上、さらに8首の漢詩も収録されているものの、流石に俳諧は収録されていない。 19世紀末から20世紀初めへの移行期に俳句は漸く格言や警句ではなく、ハイクとし

7 Léon de Rosny. Si-ka-zen-yō. Anthologie japonaise. Poésies anciennes et modernes des insulaires du Nippon. Paris: Maisonneuve, 1871.

8 Bénédicte Fabre-Muller, Leboulleux, Pierre, Rothstein, Philippe. Léon de Rosny: De l'Orient à l'Amérique, Villeneuve d’Ascq, Presses universitaires du Septentrion, 2014, p.358. 
て認識されるようになる。哲学と医学の教授であるポール・ルイ・クシュー(Paul-Louis Couchoud)が、訪日中に俳句の存在に出合ったのは、偶然だっただろうが、鬼に角、彼 はすぐにその特殊な魅力に魅了され、さらにその本質に対する敏感な感受性をも示した のであった。その結果、訪日後、1905年に友人のアルベール・ポンシン (Albert Poncin) とアンドレ・フォール(André Faure) と共にセーヌ川と関連の運河網を航行する船旅 中、72句のハイカイを作成した。因みに戦前のフランスでは八イクより寧ろハイカイ の方が一般的に使われた。これ等の句を集めて『Au fil de l'eau（流れに任せて）』と題さ れた句集(編者匿名、自家出版30部) は、西洋語で出版された八イク原作の最初の句集と 思われる。その中から芭蕉の「くたびれて宿借るころや藤の花」を連想させる一句を引用 しょう。

\author{
Dans le soir brûlant \\ Nous cherchons une auberge. \\ O ces capucines! \\ 暑い夜は／旅宿を探し／金蓮花!
}

俳句の紹介段階から受容段階への移行過程をヨーロッパの他の諸国と比較すると、フ ランスでのハイクとしての受容が逸早く実現され、ポール・ルイ・クーシューが翌年の 1906年に発表した「Les Épigrammes lyriques du Japon」(日本の叙情詩的エピグラム ${ }^{『}$ Lettres』誌1906年4月号所収) はフランスに於ける俳句の最初の本格的な評論ではあるも のの、その題名が示唆するように、著者もまだ俳句・八イク・ハイカイをどう位置づけ すべきかについて疑問を抱えていたようである。彼は、ヘンリー・D・ダボレー (Henry-D. Davray)が1902年に完成した、上記アストン編『日本文学史』のフランス語訳 も参照できた筈であるのみならず、早くも1903年にフランスの学者クロード・メート ル(Claude Maitre)が書評を公表したチェンバレンの『芭蕉と日本の詩的な警句』も知って いたと思われる。それでも、クーシューは、すでに俳句の原型の単なる模倣の段階を超 えて、最初から自分の感受性を発揮しようとして句作を試みていたことが明らかであ る。さらに、彼のこの基本的なスタンスは、その後抬頭する大勢の愛好家にとって道し るべとしても役立ったようである。その結果、早くも俳句の受容過程にさらにもう一つ の転換を辧し、輸入されたジャンルに土着性の強い方向性を与え、ジュリアン・ヴォー カンス(Julien Vocance：1878-1954)が第一次世界大戦の塹壕から世に送り出したハイカ イを詠む土壤を作ったようである。1916年の彼の「Cent Visions de Guerre(戦争の百景)」 (『Grande Revue』誌1916年5月424-435頁所収)は、ホトトギスの花鳥諷詠の作意からよほ ど遠く離れており、同時に日本趣味の時代に終止符を打ったのであった。その外に発表 された句作には90句を収録した「Fantômes d’hier et d'aujourd’hui(昨日と今日の幽霊」 (『Grande Revue」誌1917年5月475-484頁所収)、「Au Cirque(サーカスにて)」(『La Nouvelle Revue Francaise』誌1920年9月所収(クーシューその他によるハイカイも収録)、「Art 
poétique(詩の芸術)」(『La Connaissance』誌1921年6月号489-491頁所収)が挙げられる。

「Cent Visions de Guerre(戦争の百景)」(1916)から2句を引用しよう。

\author{
Des croix de bois blanc \\ Surgissent du sol, \\ Chaque jour, ça et là, \\ 白木の十字架 \\ 土から浮上す \\ 毎日、おちこちに \\ Dans un trou du sol, la nuit \\ en face d'une armée immense \\ deux hommes \\ 夜地面の穴に \\ 巨大な軍隊と直面す \\ 2人の男
}

1920年代に益々人気を博するようになり、1923年にルネ・モーブランは、48人のハ イジンによる283句のハイカイを24種に分類して収集した句集を出した9。それは西洋 に於いてはハイクの最初の書誌を含む、西洋ハイクの史上最初のアンソロジ一と思われ るものであった。

\title{
5 ヨーロッパの主流文学
}

一方、ヨーロッパの諸国では、フランスとは違い、それこそエストニア、ギリ シャ、ラトビア、セルビア、またはスウェーデンでそうであったように、受容の初段 階は、殆どの場合、アンソロジーまたは日本文学史の形態を取って、日本語の原句の翻 訳を通じて行われた。

また所謂主流文学にも八イカイが注目されるようになる。ドイツにおいては、ライ ナー・マリア・リルケ(Rainer Maria Rilke)、フランツ・ブレイ(Franz Blei)、イヴァ ン・ゴル(Ivan Goll)、クラバンド(Klabund)などが挙げられる。カール・フリードリ ヒ・ポール・エルンスト(Carl Friedrich Paul Ernst：1866-1933)の詩集『Polymeter(ポリ メーター)』(1898)に収載された次のハイクがドイツ語圏における最も早い一例である。

Eine Wasserrose

Die aus der Tiefe auftaucht.

9 René Maublanc. "Le haïkaï français, bibliographie \& anthologie" in Le Pampre Revue régionale de littérature \& d'art; organe du cercle Chevigné 1923. n ${ }^{0} 10 / 11,2^{\mathrm{e}}$ Année. 
Kräuselt sich das Wasser.

水蓮

深みから出現す

水の波紋

フランスに於いては、ジャン・ポールハン(Jean Paulhan)、ポール・エルアール (Paul Éluard)、ポール・ヴァレリー(Paul Valéry)、ポール・クローデル(Paul Claudel) を挙げなければならない。中でも詩人、詩劇が最も有名な劇作家、外交官であったポー ル・クローデル(1868-1955)の俳諧的詩集『Cent phrases pour éventails（百扇帖』(1927) は特筆すべきである。スペインに於いては、アントニオ・マチャド(Antonio Machad o)、ノーベル賞受賞者のフアン・ラモン・ヒメネス(Juan Ramón Jiménez)、ラファエ ル・アルベルティ(Rafael Alberti)、ルイス・セルヌーダ(Luis Cernuda)、またはギリ シャのノーベル賞受賞者ジョルゴス・セフェリス(Giorgos Seferis)など、所謂主流の詩 人も新しく紹介されたジャンルに注目して、場合によっては句作に挑戦している。

中には、俳句そのものの形式を採用しなくても、ハイカイのものの見方と精神を自 分の詩作に織り込もうとする詩人もいた。ドイツ語文学の泰斗リルケ(Rilke) という詩人 は、数多くのドイツ語の詩を書いた外に、1923年から1926年までに、四百篇余りのフ ランス語詩をも書いた。その内のフランス語連作詩『Les Roses(喵薇)』(1924-26)にはと りわけ俳句の影響が濃厚に窅える。リルケの蔵書にポール-・ルイ・クーシュー著『Sages et Poètes d’Asie(アジアの賢人と詩人)』(Calmman-Lèvy1919年版、初版は1917年）が含ま れていたことは、前から知られた事実であった。が、従来の説では、その購入年はフ ランス語連作詩成立後の翌年、1925年であったため、『薔薇』を執筆の際、その本による 影響はあり得なかいということになっていた。ところが、その購入年の想定が誤り で、正しくは1920年10月であったと先行研究の成果として明らかになった ${ }^{10}$ 。リルケが 初めて俳句に接したのは、富士川氏などが述べているように1920年9月、『La Nouvelle Revue Française（新フランス評論）』(「Haï-kaï」1920年9月1日)、「ハイカイ特集号」に掲載 されたフランス語訳を介してであった ${ }^{11}$ 。同特集号の序文では、ジャン・ポーランが俳 句を簡単に紹介し、「絵画的で、神秘的である」と前置きしてから、クーシューの三行書 きの仏訳による、三句のハイカイ作品を引用している。さらに幾人かのフランスのハ イカイ詩人の作品も紹介し、この「ハイカイ」特集が新しい詩のジャンルの土台を形成す ることを祈願すると、編集企画の抱負を述べている。

1920年9月4日、リルケは「ハイカイ」を初めて知った感動を、日本に滞在したことの あるグデイー・ネルケ夫人宛の手紙に「あなたは短い日本の(三行の)詩形をご存じです か」と表現している。特に鬼貫の一句「咲くからに見るからに花の散るからに」に深い感

10 Herman Meyer. “Rilkes Begegnung mit dem Haiku.” in Euphorion, Bd. 74, 1980, pp.134-168.

11 富士川英樹「リルケと日本」(東大比較文学会編『比較文学研究』第8号, 1964). Fujikawa, Hideki(1964) Riruke to Nihon, Hikaku bungaku kenkyu Vol. 8. 
銘を受けて、絶賛の言葉を惜しまなかった。以下の仏語訳を引用しているが、それ自体 がチェンバレンの英訳(“They blossom forth, and so I gaze, / And so these flowers fade, and so..”[Chamberlain 1902: 246])に基づくものであった。

\author{
Elles s'épanouissent, - alors \\ On les regarde, - alors les fleurs \\ Se flétrissent, - alors
}

そして9月初旬、「Hai.Kai」と題して、ただちに三行書きの最初の実作をフランス語で 試みている。リルケの蔵書『アジアの賢人と詩人』には、ほぼ全体に自筆の鉛筆による傍 線などの書き込みが遺されている。俳句に関する第2章「Les épigrammes lyriques du Japon(日本の抒情的短詩)」には、取り分けその痕跡が多くみられ、リルケがこの章を丹 念に読んでいたことが分かる。この章では、クーシユーはまずハイカイ総論に六頁 （53-58頁）ほど紙面を割いて、俳句の定義、特質、起源、作者などについて、また日本 の版画などと比較しながら簡単に紹介した後、さらに具体的に俳句を約70頁(59-123頁) ほど訳出して、注勫も付けている。総論では、ハイカイの一般的な特徴は大胆なほどの 単純化であり、ハイカイは一枚の日本風クロッキー(croquis japonais：日本風の素描)に 比較できる (55頁) という俳論を打ち立てている。「(ハイカイ)は我々の目に直接訴えて くる一つのヴィジョンであり、我々の心に眠っている何かの印象を目覚めさせてくれ る生き生きとした一つの印象である」とし、それが視覚的な要素、換言すれば写象であ ることを主張している。

それを裏付ける具体的な例として矢張り荒木田守武の有名な一句の仏語訳を引用して いる。

Un pétale tombé

Remonte à sa branche :

Ah, c'est un papillon!

ひとひらの落ちた花びら

再び枝にのぼる

ああそれは蝶

Arakida Moritake (1472-1549).

(原句：落花枝にかへると見れば胡蝶かな $)^{12}$

「この最後に示した例は典型的なものである。ひとつの短い驚きにれが俳句の定義そ のものである」と、編者が付け加えているところにリルケは下線を引いている。矢張り

12 Yoriko Shibata. "The Influence of Haiku on Rilke" in Interlitteraria (Interlitteraria), issue : 03 / 1998, pp.335-345, on www.ceeol.com. 更に、柴田依子「リルケの俳句世界」(日本比較文学会編『比較文学』第35号, 1992), pp.89-101. 
特に瞬間的な感動を示すところが感銘を受けたポイントであったのであろう。

更に注意を引きたいことは、17音字を守るクーシューの姿勢である。それに関連し て面白い逸話が思い出される。1936年(昭和11年)頃、高浜虚子がヨーロッパを旅行した 時、クーシューと夕食などを共にしていた。その際、クーシューは俳句の17音節とい う規則に大変興味を示して、その特徵を盛んに強調していたのに対して、虚子は17音節 でなくても良い、と言っていたので大変驚いたそうだ。17音節は日本語だからやれる のだが、日本語以外の言葉で17音節にする必要はない。それよりも季題(季語)、自然を 中心に詠うことが俳句の真䯣だからそう思ってくれ、と虚子は念を押したという。

リルケの心の琴線に触れたのは、特に視覚的な要素、詰り俳句の写象的な表現であっ た。それに関連して20世紀初頭の英国とアメリカの詩人たちによるイマジスト運動に触 れなければならない。自由律詩を書いていた彼らの抱負は、「clarity of expression through the use of precise visual images(正確な視覚に訴える写象の使用による表現の 明確さ)」を目指すことにあった。エズラ・パウンド(Ezra Pound)が1912年にヒルダ・ ドゥーリトル(H. D./Hilda Doolittle：1886-1961)が送信した詩「Oread」を受け取って読 んだ時、そこに「H.D.イマジステ」と勝手に筆名を入机て、Blast』という雑誌の1914年 の創刊号に入稿して掲載させたのが運動の嚆矢と言われている。同詩を引用しよう。

\author{
Whirl up, sea - \\ whirl your pointed pines, \\ splash your great pines \\ on our rocks, \\ hurl your green over us, \\ cover us with your pools of fit $^{13}$
}

勿論俳句ではないが、俳句らしい要素を豊富に含んでいる、あるいは俳句と通じ合 うところがあるというのが、パウンドの考え方だっただろう。

このイマジスト運動は、トーマス・アーネスト・ヒューム(T.E Hulme)によって提言 されたアイデアから生まれた。ヒュームは、1908年にロンドンの『Poets'Club』に、過 度の言葉遣いを避けて主題を絶対に正確に表現することを基調にした詩作論を提起し た。イマジスト・マニフェストの最初の信条は、「一般的な口語の言葉を使用するが、 大体正確な単語や単なる装飾的な単語ではなく、常に厳密に正確な単語を使用すること」 であった。パウンドのイメージの定義は、「知的且つ感情的複合体を瞬間に提示するも の」と。パウンドは、イマジストの詩論を次のように定義した。

I ．主観的であ万うと客観的であ万うと、「もの」の直接的な扱いのこと。

II . プレゼンテーション (写象) に寄与しない言葉を一切使用しないこと。

13 Ezra Pound, 'Vortex', BLAST, no. 1(20 June 1914), pp.153-154. 
III.リズムに関しては：メトロノームの順序ではなく、音楽のフレーズの順序に 沿って作詞すること。

詩論と詩作の運動としては、1917年にイマジスト運動に終止符が打たれたのだが、 20世紀の自由律詩人に深い影響を及ぼしたことは事実である。代表的な写象主義者ウィ リアム・カーロス・ウィリアムズ(William Carlos Williams：1883-1963)の詩を一首引用 しよう。

The red wheelbarrow
so much depends
upon
a red wheel
barrow
glazed with rain
water
beside the white
chickens
赤い手押し車
白い鶏の傍に
釉薬のような雨水に
覆われた
赤い手押し車に
依るところは多々ある

以上示したように、第一次世界大戦後、俳句の本質、真䯣と思われるものが西洋の詩 人の一部に注目されていたが、それを本格的なハイクの実作に結び付ける土壤はまだで きていなかった。両世界大戦間の政治的社会的混乱を伴う20世紀前半という環境は、八 イクを培う沃地ではなかったかも知れない。その結果、ハイクに対する関心は、フラ ンスを含めて、1930年代に入って段々下火になっていき、最終的に殆ど瀕死に近い状態 に陥ってしまう。

\section{6 第二次世界大戦後}

決定的な復興の切っ掛けとなったのは、1949年から 1952年までの間に北星堂から出 版されたレジナルド・ホーラス・ブライス(Reginald Horace Blyth:1898-1964)の編集 した俳句英訳とその解説を含めた4巻本の『Haiku，4 vols(俳句)』(1949-1952)であった。 
さらに『Senryu: Japanese Satirical Verses』(1949)、『A History of Haiku, 2 vols』 (1963-1964)も世に送られた。ブライスの権威と説得力は、彼が「本物」だったというこ とにあった一大学の教授で、日本人の女性と結婚していたものの、それでも日本が戦 争に入った時に敵国人として抑留されたにも拘わらず、日本の生活と文化のあらゆる側 面にひたすら慣れる努力を払ったのに加えて、明仁皇太子の家庭教師にもなり、死ぬま で25年間日本に住み続けた。ブライスの傑出した編著は、西洋諸国における俳句の認識 と普及に大きく寄与したに相違ない。終戦直後の段階では、戦後の総決算の問題がまだ 尾を引いており、直ぐには反響を呼ぶに至らなかったが、70年代に入ってからは漸く各 国で大きく注目され、それぞれの国でその国のレベルにおいて翻訳、翻案と原句製作の 刺激となった。

日本国外の俳句専門誌が始めて創刊を見るに至ったのは、ウィスコンシン州プラッ トビル(Platteville)市に1963年に創刊されたジェームス・ブル(James Bull)とドン・ユー

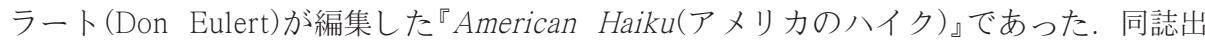
版以前は、殆どの八イジンは新聞や小さな雑誌に投稿していた。ヨーロッパでも同様で あったが、句集を単行本として出版する傾向が段々現れた。こうして例えば、べルギー のバルト・メソッテン(Bart Mesotten)は、1972年にその処女句集『Dag、haikoe(ハイク ようこそ)』を始め、12冊以上の句集を出版するのに加えて、1976年にHCV (Haikoe Centrum Vlaanderen/Haiku Center of Flanders：フランダース・ハイク・センター)を設 立し、1980年に現存する最古のヨーロッパの俳句雑誌『Vuursteen(火打石)』を創刊するな ど、正に40年間、オランダ語圏におけるハイク文学の隆盛に大きく寄与したのである。 1973年にオランダ人ファントーレン (J. van Tooren J.)は、多数の日本語の原句をオラ ンダ語に翻訳して『Haiku - Een jonge maan(ハイク若き月)』という題名の選集を世に 送った。この不朽の名訳は、オランダ語圏に於けるハイク愛好家やハイジンの間に、古 典的な存在として持て唯され、版を重ねた画期的な出版となった。また、バルカン半島 万面では、ウラジミール・デビデ(VladimirＤevidé)が1975年に出した『Japanese Haiku Poetry and its Cultural -Historical Setting(日本の俳句とその文化的・歴史的条件)』も模 範的な俳句入門書となっている。

さらに1970年代に翻訳の第二波が始まり、例えばフランスではモーリス・コヨード

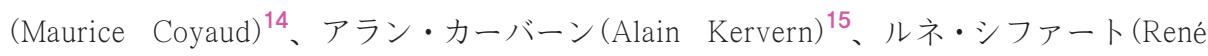
Sieffert)、またはジョアン・テイタス・カーメル(Joan Titus-Carmel)など優れた翻訳者 が輩出している。このようにして1970年代からは、各国語への翻訳者が続々と輩出する のに次いで、各国に俳句協会が誕生する機運も熟していったのである。1980年には 「HKN Haiku Kring Nederland(オランダハイク協会)」、1988年に「DHG Deutsche Haiku Gesellschaft(ドイツハイク協会)」、1990年に「BHS British Haiku Society(英国ハイク協

14 Maurice Coyaud. Fourmis sans ombre - Le livre du haïku, Paris : Phébus, 1978.

15 Alain Kervern. Grand almanach poétique japonais, Livres I-V, Mayenne : Folle Avoine, 1988-1994. 
会)」、1991年には「ルーマニアハイク協会」、1992年には「クロアチア・ハイク協会」, 1993年には「ユーゴスラビア連邦ニシュ市のハイククラブ「マサオカシキ」、2000年には 「ブルガリア・ハイク・クラブ」、2003年には遅れ馳せながら「AFH Association francophone de haïku(フランス語八イク協会)」などである。しかし、今までのところ、 例えばスペインにもイタリアにも公式の全国的レベルでのハイク協会は存在していな い。が、その反面、小さなサークルや地域グループは、その抱負として全国的なグ ループに負けじと熱心な活動を繰り広げているのが現状である。スペインとイタリア の場合、アカデミックな色彩の強い「AGHA Asociación de la gente del haiku en Albacete(アルバセテの俳句協会)」とトリノの近くの「Cascina Macondo Centre(カッシー ナマコンドセンター)」を挙げなければならない。

結局、ハイク受容のこの第2段階は、俳句ジャーナルの創刊、句集の出版事業、句会 の開催、吟行、俳句コンテスト、さらには国際フェスティバルなど、多種多様の活動を 繰り広げている観を呈している。1992年と1994年にコンスタンツア(ルーマニア)での 国際ハイクフェスティバル、また2005年に17か国から61人もの参加者が集まったバー ト・ナウハイム (Bad Nauheim：ドイッ)での全ヨーロッパ規模でのフェスティバル、 2007年に15か国から56人の参加者が集まったヴァデステーナ(Vadstena：スウェーデン) でのフェスティバル、2010年に20か国から33人の参加者が集まったゲント(ベルギー) でのフェスティバルなど、続々と国際フェスティバルが開催された。

またイオン・コッドレスク (Ion Codrescu)は、1992年から2002年までルーマニア語 と英語の二ヶ国語での国際雑誌『AlbatrosS』を編集し、さらに1995年から2002年までの 『Woodpecker』(Willem Lofvers \& Milivoj Objedović編集)には、オランダ語と英語の翻 訳と併記して原句を掲載するといった複数言語使用の試みも見られた。しかし、2000年 代に入ってから、ハイクの国際化に向けて最も重要な一役を買ったのは、インターネッ トの発展によるコミュニケーションの新しい可能性である。例えば、スペインには 『H.E.L.A.(Hojas en la acera/'Leaves on the Pavement')』、またドイツ語と英語で出版 されたバイリンガルの『Chrysanthemum(菊)』など、デジタル雑誌が登場した。また、 2013年春以降、ポーランドの共同編集者(Krzysztof KokotとRobert Kania)は、『European Quarterly Kukai(欧州の季刊句会)』を創刊し、51か国からの284人の参加者を集めて4号 まで出版している。このようにして俳句の共有に新しい次元が出現した。メール、 チャットルーム、フォーラム、ブログ、ウェブサイトなど多種多様の直接なコミュニ ケーションの方法がハイクの隆盛に更なる門戸を開いている時代は到来している。

\section{7 おわりに}

本論では、欧米、主として欧州における俳句・ハイクの導入、翻訳、翻案、採用及び 
欧州独自のハイク形式の形成について概観してみた。初段階では、翻訳者によってエピ グラムに似たものとして紹介されたが、20世紀初めからフランスを初め徐々に俳句の 特徵が理解されるようになり、欧州各国語でも八イクの創作の試みが見られるように なった。1920年代には欧州独特の感受性と感覚を表現した八イクを詠む八イジンが多く 輩出すると同時に、主流文学者の中にも俳句の作意を会得して西洋の詩形に織り込もう とする試みをなすものも見られた。そして第二次大戦後、古典俳句へ遡及して数多くの 俳句を英訳し、解釈を付した、ブライスの諸種訳書が世界的な反響を呼んで、各国でそ れぞれの国の言葉で八イクが製作される土壌が作られていった。その結果、1970年代か ら、ハイクが国際的なジャンルとして定着していき、現在世界のハイジンの人口が相当 な数になっているのが事実である。正しくハイクのグローバル化といえるだろう。

\footnotetext{
参考文献

富士川英樹(1964)「リルケと日本」(東大比較文学会編『比較文学研究』第8号). Fujikawa. Hideki (1964) Riruke to Nihon, Hikaku bungaku kenkyu Vol. 8.

柴田依子 (1992)「リルケの俳句世界」(日本比較文学会編『比較文学』第35号. Shibata, Yoriko (1992) Riruke no haikusekai. Hikaku bungaku Vol. 35.

Aston. William George (1877) A Grammar of the Japanese Written Language.

Aston. William George(1898) A History of Japanese Literature.

Barnhill. David Landis (2004) Bashō's Haiku. New York : Suny Press.

BLAST. London : John Lane, 1914-15.

Blyth, Reginald Horace (1949-1952) Haiku. 4 vols. Tokyo : Hokuseido.

Blyth, Reginald Horace (1949) Senryu : Japanese Satirical Verses. Tokyo : Hokuseido.

Blyth, Reginald Horace (1963-1964) A History of Haiku. 2 vols. Tokyo : Hokuseido.

Chamberlain. Basil Hall (1880) The Classical Poetry of the Japanese.

Chamberlain, Basil Hall (1888) A Handbook of Colloquial Japanese.

Chamberlain. Basil Hall (1902) Bashō and the Japanese Poetical Epigram. Transactions of the Asiatic Society of Japan. Vol. 2. No 30

Chamberlain. Basil Hall (1905) Things Japanese. London : John Murray.

Hartman, Sadakich (1916) Tanka and Haikai : Japanese Rhythms. San Francisco.

Hearn, Lafcadio (1903) Kottō : Being Japanese Curios, with Sundry Cobwebs. New York : The Macmillan Company.

Kacian, Jim. Philip Rowland, Allan Burns eds(2013) Haiku in English: The First Hundred Years. New York /London : W.W. Norton \& Company.

Noguchi, Yone (1914) Through the Torii. Boston : Four Seasons Company.

Oseko Toshiharu (1990) Basho's Haiku.

Shibata, Yoriko (1998) "The Influence of Haiku on Rilke" in Interlitteraria (Interlitteraria).

The Fortnightly Review 571. September 1. 1914.

Trumbull, Charles (2010) "One Hundred Bridges, One Hundred Traditions in Haiku - Part I", in Modern Haiku, An Independent Journal of Haiku and Haiku Studies, Volume 41.2. Santa Fe NM. Summer.
} 
Ueda. Makoto91992) Bashō and his Interpreters. Stanford: Stanford University Press.

Claudel. Paul (1927) Cent phrases pour éventails. 3 vols. Tokyo : Koshiba.

Couchoud. Paul-Louis (1905) Au fil de l'eau.

Couchoud, Paul-Louis (1906) "Les Épigrammes lyriques du Japon" in Lettres, Avri.

Couchoud. Paul-Louis (1917) Sages et Poètes d'Asie. Paris : Calmman-Lèvy.

Coyaud, Maurice (1978) Fourmis sans ombre - Le livre du haiku. Paris : Phébus.

Fabre-Muller, Bénédicte, Leboulleux, Pierre, Rothstein, Philippe(2014) Léon de Rosny: De l'Orient à l'Amérique,

Villeneuve d'Ascq. Presses universitaires du Septentrion.

Kervern, Alain (1988-94) Grand almanach poétique japonais, Livres I-V. Mayenne : Folle Avoine.

Maublanc, René (1923) "Le haïkaï français, bibliographie \& anthologie" in Le Pampre Revue régionale de littérature \& d'art: organe du cercle Chevigné 1923. n 10/11. $2^{\mathrm{e}}$ Année.

Rosny. Léon de(1871) Si-ka-zen-yō. Anthologie japonaise. Poésies anciennes et modernes des insulaires du Nippon. Paris : Maisonneuve.

Vocance, Julien (1916) "Cent Visions de Guerre" in Grande Revue Mai.

Vocance, Julien (1917) "Fantômes d'hier et d'aujourd'hui" in Grande Revue Mai.

Vocance, Julien (1920) "Au Cirque" e.a. in Hai-kaii. La Nouvelle Revue Francaise. 1 Septembre.

Vocance, Julien (1921) "Art poétique" in La Connaissance Juin.

Meyer. Herman (1980) "Rilkes Begegnung mit dem Haiku." in Euphorion. Bd. 74.

Tooren, J. van (1973) Haiku - Een jonge maan: Japanse haiku van de 15e eeuw tot heden. Amsterdam:

Meulenhoff. 